\title{
Back to Basics: Is Civic Agriculture the Solution to Food Deserts in Texas?
}

\author{
Faye Anderson, Keith Burau \\ Texas A \& M Agri Life Research Center, Beaumont, USA \\ Email: andersonfaye7@gmail.com
}

Received 8 April 2015; accepted 5 May 2015; published 8 May 2015

Copyright (C) 2015 by authors and Scientific Research Publishing Inc. This work is licensed under the Creative Commons Attribution International License (CC BY). http://creativecommons.org/licenses/by/4.0/

(c) $\underset{\mathrm{EY}}{\mathrm{B}}$ Open Access

\section{Abstract}

Fair access to fresh fruits and vegetable is an important aspect of a healthy civil society. This study investigates the potential of farmers markets to transform food deserts of Texas into oases. Data for age, sex, race, income, grocery store access, and farmers markets in Texas were obtained from the US Department of Agriculture (USDA) Economic Research Service Food Environment Atlas and the US Census Bureau, in order to investigate the association between civic agriculture in the form of farmers markets and food insecurity in Texas. Data were statistically analyzed and spatially investigated. Spatial analysis of the distance to nearest farmers market suggests a strong inverse correlation between the distribution of civic agriculture activities and food deserts. These results encourage non-farmers transition to farming careers and help local farmers in Texas improve their competitiveness, preserve their farming traditions, and contribute to their societal and economic development.

\section{Keywords}

Food Desert, Texas, Farmers Market, Master Gardner, Civic Agriculture, Sustainable Agriculture, Civil Society

\section{Introduction}

"The world food order is increasingly fragile, supplemented by ad hoc food assistance programs, and countered by alternative agricultures" [1]. Food systems in the world are the basis for food production, the social characteristics of behavior, and the governmental programs associated with these activities [2]. Due to the increased complexity of food insecurity in a highly developed country like the US, more diversified research has been conducted in order to demystify its causes. On average, food travels more than $1600 \mathrm{~km}$ from farms to plate [3] 
and more than $15 \%$ of American households were located in food deserts [4]. Having one of the fewest supermarkets per capita [5], Texas' food system disconnect is one of if not the worst nationwide.

Mainstream US food system is of global large scale where farmers, corporations, and government programs synchronize their activities in order to ensure food security. Nevertheless, a network of "Smaller-scale, locally oriented, flexibly organized farms and food producers" [6] has been progressing all over the country in order to close the gaps in food shortages. The idea of civic agriculture is the origin of current industrialized food system which offers hope of connecting the broken social ties and ailing communities. Civic agriculture in general can be grouped into five main categories: home gardeners, community gardeners, charity growers, educational gardeners, and market growers [7] [8]. Multifaceted inter-correlated factors are inherent to each of these measures. Preliminary research has not proven its affordability [9] [10]. Examples of spatially spreading food models in Texas include farmers market, food coops, and master gardeners.

Although there is evidence that small-scale, local agricultural models positively affect social and community ties, the literature is inconclusive about the social benefits of civic agriculture [11]-[13]. Can a small local farmer's market or a food coop break the cycle of a global or a national unevenly distributed food system? The purpose of this study is to thoroughly examine this possibility for a distinctive state like Texas. Establishing food system fairness is essential to a civic society where social aspects connect the economy with the state [14]. The study of access to fresh food in Texas measures the extent to which civic agriculture is fostering fairness in the state's food system. Despite the presence of many governmental programs like the Farm Bill, Food Surplus Commodities Corporation, and Food Stamp Program; field crops benefit most from the mainstream industrialized food system [6] [15], indicating the increased demand for food security [16] especially for low income residents.

Researchers have different views of the role of civil society. Some argue that it has the ability to fortify and build itself by some people's united actions as in the example of civic groups that are active in the community and its politics [17]. Others see the need for the government to take care of all the community needs [18] while others argue that the society needs to embed economic transactions in its structure but with prioritizing individuals' needs [6]. Applying this to food system, by incorporating local food systems within the society in the form of civic agriculture, the community can strengthen its social links, which supports justice in the food system.

\section{Methods}

\subsection{The Data}

The geographic location for this study is all the census tracts in Texas. Three datasets were linked: food deserts [19], age and sex statistics by census tract [20], and the list of farmers markets in Texas [21]. According to USDA, a food desert is a "census tract with a substantial share of residents who live in low-income areas that have low levels of access to a grocery store or healthy, affordable food retail outlet" [19]. Low-income census tract has a poverty rate of $20 \%$ or higher or a median family income at or below $80 \%$ of the tract's median family income. A census tract is labeled as low-access if 500 or more of its residents or $33 \%$ of its population live more than half a mile (for urban areas) from a grocery store or 10 miles (for rural areas) [19]. This data is recorded in a binary (1/0) variable named $Y=$ Low income and low access measured at $1 / 2$ for urban areas and 10 miles for rural areas. Moreover, cropland data [22] was extracted in order to study the main crops of texas.

\subsection{Logistic Regression}

Logistic regression was conducted to measure the association between the dichotomous dependent variable $(\mathrm{y}=$ low income and low access measured at $1 / 2$ and 10 miles) and the independent variables. The logistic model assumes that the logit of the probability for $\mathrm{Y}$ is a linear function of the independent variables distance to nearest farmers market. The logit of a probability $\mathrm{p}$ is defined as $\log (\mathrm{p} / 1-\mathrm{p})$, where log represents the natural logarithm [23]. Logistic regressions were conducted for each of the risk factors: males (\%), females (\%), median age (\%), males median age (\%), females median age (\%), white (\%), black (\%), American Indian (\%), Asian (\%), other races (\%), number of housing units, urban tracts (\%), rural tracts (\%), census tract population (\%), and distance from the center of the census tract to the nearest farmers market (mile). Then a combined model was developed including the risk factors that were statistically significant (p-value less than significance level of 0.05 ). Odds rations (OR) were calculated for these models. 


\section{Results}

Texas has 254 counties and more than 5250 census tracts. More than 37\% of Texan census tracts are located in food deserts. Summary of Texas food desert aspects are presented in Table 1. The two highest measured variables that combined low income and low access were "low income and low access measured at 1 and 10 miles" and "low income and low access measured at $1 / 2$ and 10 miles" with 21 and 38 percentages respectively. Urban areas make up the majority of the state (78\%) whereas $22 \%$ is rural. While $94 \%$ of the residents have access to a grocery store within 10 miles, 46\% are of low income. On average males and females represent $50 \%$ of the census tracts” populations. Median Age is 35 years, males median age is 34 years, and females median age is 36 years. In 2010, 74\% of the residents were white, 12\% were black, 1\% were American Indians, 4\% were Asian, and other races including Hispanics were 9\% (Figure 1).

There are 200 farmers markets in Texas. Only 55\% of them are active year-round and only $18 \%$ accept cash. About 52\% offer fresh vegetables and only 9\% offer fresh fruits. Whereas 55\% offer wild harvest and 65\% sell prepared food. Only $12.5 \%$ offer organic produce (Table 2). A map of their locations as well as areas of low income and low access at 1/2 and 10 miles is given in Figure 2. The majority of farmers markets are located in areas with higher population density like Houston, Austin and Dallas. Their spatial distribution is inversely associated with areas of food insecurity in the state.

\begin{tabular}{lcc} 
Table 1. Demographics of Texas residents 2010. & & \\
\hline Group & $5 u m b e r$ & $\%$ \\
\hline Total & 1093 & 100 \\
Low income and low access measured at 1 and 10 miles & 1994 & 38 \\
Low income and low access measured at $1 / 2$ and 10 miles & 993 & 19 \\
Low income and low access measured at 1 and 20 miles & 918 & 17 \\
Low income and low access using vehicle access & 4107 & 78 \\
Urban tract & 1151 & 22 \\
Rural tract & 5020 & 95 \\
Low access tract at $1 / 2$ mile & 3418 & 65 \\
Low access tract at 1 mile & 330 & 6 \\
Low access tract at 10 miles & 30 & 1 \\
Low access tract at 20 miles & 1215 & 23 \\
Vehicle access-tract with low rate & 2419 & 46 \\
Low income & &
\end{tabular}

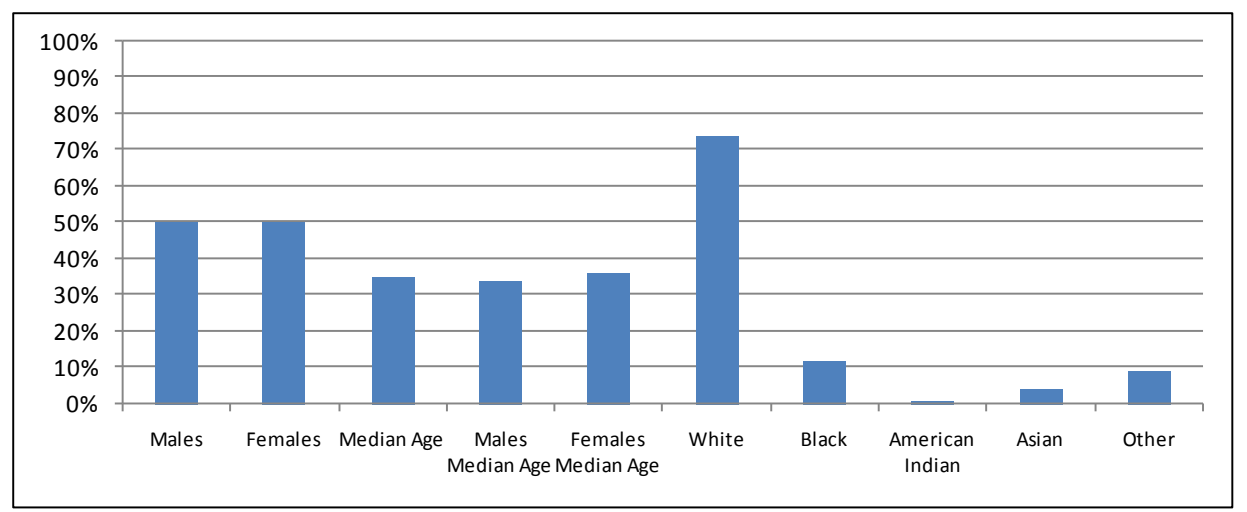

Figure 1. Locations of Farmers Market in Texas 2015. 
Table 2. Categories of farmers markets in Texas.

\begin{tabular}{ccc}
\hline Market Category & Count & Percentage \\
\hline Total & 200 & 100 \\
Seasonal & 91 & 45.5 \\
Year Round & 109 & 54.5 \\
Accept Cash & 18 & 9.0 \\
Fresh Vegetables & 105 & 52.5 \\
Organic Produce & 25 & 12.5 \\
Fresh Fruits & 9 & 4.5 \\
Wild Harvest & 110 & 55.0 \\
Prepared Food & 65 & 32.5 \\
\hline
\end{tabular}

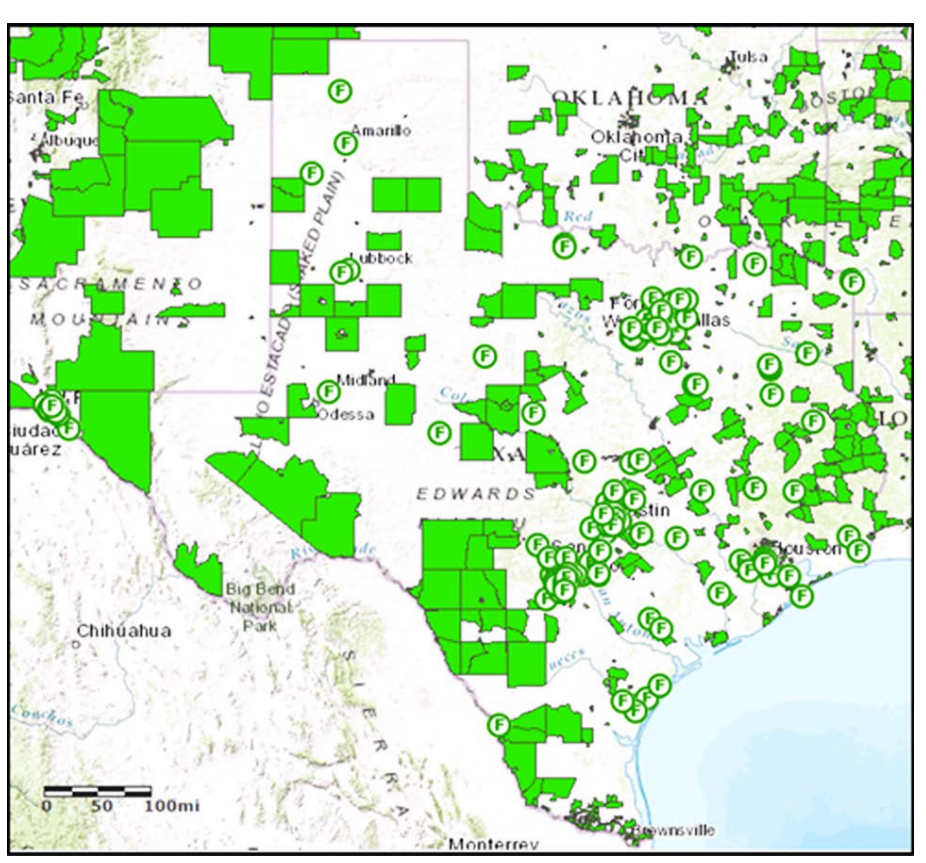

Figure 2. Texas farmers markets (F) and areas of low income and low access at 1/2 (urban) and 10 miles (rural) in 2010.

The distance between a census tract's center to nearest farmers market was calculated for each of the 5258 tracts and merged to the demographics dataset. Bivariate analyses of unadjusted odds ratios found that gender, median age, race, population and distance to nearest farmers market were associated with Y (low income and low access measured at 1/2 for urban and 10 miles for rural tracts) (Table 3). Females have $10 \%$ higher chances to live in or near a food desert than males, African Americans have 3\% higher odds than other races, American Indians have $7 \%$ higher odds than other races, and other races have $9 \%$ higher odds. Also, living in an urban area increases a resident's odds to be in a food desert are $635 \%$ higher and the higher the distance to farmers market the higher the odds to suffer from food insecurity.

For the second logistic regression analysis, only those with p-value less than 0.05 and OR greater than one from the unadjusted logistic regressions in the previous step. These are presented in Table 4. They were all statistically significant except the percentage of American Indians (p-value 0.20). Odds ratios were similar to those calculated in the unadjusted bivariate regression. Finally, corn (14\%), cotton (30\%), rice (10\%) and sorghum (15\%) were the four highest Texan cash crops in 2010 (Figure 3). 


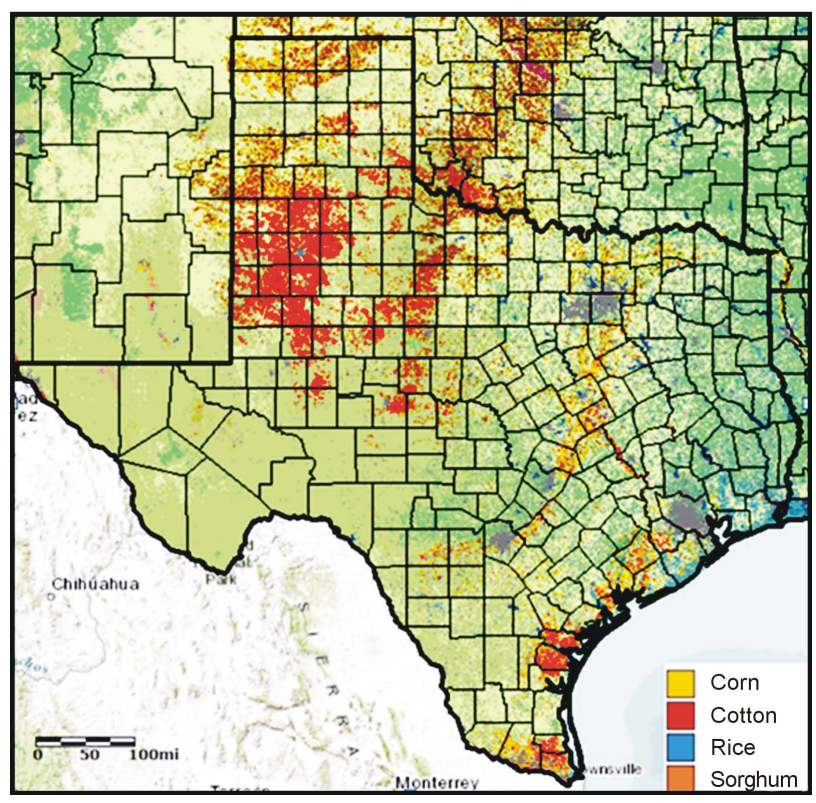

Figure 3. Main four crops in Texas.

Table 3. Unadjusted odds ratios for the risk factors for Texas census tracts 2010.

\begin{tabular}{cccccc}
\hline Variable (N 5258) & Mean & OR & P value & \multicolumn{2}{c}{$95 \%$ CI } \\
Males & $50 \%$ & 0.99 & 0.05 & 0.97 & 1.00 \\
Females & $50 \%$ & 1.01 & 0.05 & 0.99 & 1.02 \\
Median Age & $35 \%$ & 0.87 & 0.00 & 0.86 & 0.88 \\
Males Median Age & $34 \%$ & 0.87 & 0.00 & 0.86 & 0.88 \\
Females Median Age & $36 \%$ & 0.89 & 0.00 & 0.89 & 0.91 \\
White & $74 \%$ & 0.97 & 0.00 & 0.97 & 0.98 \\
Black & $12 \%$ & 1.03 & 0.00 & 1.02 & 1.04 \\
American Indian & $1 \%$ & 1.07 & 0.02 & 1.01 & 1.13 \\
Asian & $4 \%$ & 0.93 & 0.00 & 0.91 & 0.94 \\
Other Races & $9 \%$ & 1.09 & 0.00 & 1.08 & 1.10 \\
Housing Units & 1697 & 0.99 & 0.00 & 0.99 & 0.99
\end{tabular}

\section{Discussion}

Overall, this study supports the theory of increasing the number of fresh food outlets can combat spread of food deserts. The spatial distribution of farmers market has significant association with food insecurity in Texas. The relationship holds true even when adjusting for race and type of area (urban/rural). Census tracts in food deserts have many correlated factors that call for a more thorough investigation; where the factors of age, sex, race, income, obesity, education attainment, and health risk can be investigated concurrently in order to understand the effects of their interactions.

While previous nation-wide research concluded that farmers markets were not significant for the whole country but were significantly inversely associated to health issues like obesity rates [11]-[13], the findings from this 
Table 4. Odds ratios adjusted by the risk factors for Texas census tracts 2010.

\begin{tabular}{cccccc}
\hline Variable $(\mathrm{N}=5258)$ & Mean & OR & P value & \multicolumn{2}{c}{$95 \%$ CI } \\
\hline Black & $12 \%$ & 1.03 & 0.00 & 1.02 & 1.03 \\
American Indian & $1 \%$ & 1.04 & 0.20 & 0.98 & 1.10 \\
Asian & $4 \%$ & 0.89 & 0.00 & 0.87 & 0.91 \\
Other Races & $9 \%$ & 1.08 & 0.00 & 1.07 & 1.10 \\
Urban & $78 \%$ & 7.30 & 0.00 & 5.90 & 9.10 \\
Distance to Farmers Market (mile) & 948 & 2.03 & 0.00 & 1.99 & 2.07 \\
\hline
\end{tabular}

study suggest a number of interesting implications of the potential of civic agriculture to resolve food insecurity in Texas. Being black increases a Texan's resident odds of being in a food desert by $3 \%$, by $1 \%$ for American Indians, $4 \%$ for Asians, and 9\% for other races. Living in an urban census tract increases the odds of being in a food desert by $630 \%$ and for each 1 mile increase in distance to farmers market, there is a $103 \%$ increase in the odds of being in a food desert. Additionally, the spatial distribution of civic agriculture activities is inversely correlated with that of food deserts. Also, most of the cash crops are produced following a large-scale manner which contributes both to the state's wealth and to the increasing gap of fresh food supply. Finally, in this study age and gender did not have any visible effect on the odds of suffering from food insecurity.

With regards to community's health, some researchers argue that civic agriculture in the form of farmers market provide a superior alternative to large superstores that are neatly stacked with everything a customer needs, because their produce is local, seasonal, supports family farmers, and encourages consumers to prepare their own meals rather than relying on highly processed quick to prepare food [24] [25]. Another documented benefit for small locally owned businesses is that they provide venues for the community to "come together and develop social bonds and a sense of trust” [26].

According to the US Census Bureau State-to-State Migration Flows data, Texas received hundreds of thousands of immigrants who are mostly unemployed African Americans from Louisiana because of hurricanes and in the pursuit of a better life in a wealthy state like Texas [27] [28]. This socioeconomic factor increases the need for fresh food supplies especially for under-served under-represented minorities. Having farmers markets in such neighborhoods can provide access to fresh fruits and vegetables, create jobs, and bring the community together.

\section{Conclusion}

The aim of this study was to investigate the potential of civic agriculture in the form of farmers markets to solve the problems of food insecurity in Texas. There is strong evidence that a spatially distributed network of farmers markets in Texas has the potential to break the cycle of low-income low-access as well as strengthening the ties of the community. Yet, this conclusion need not to be taken for granted because of the many factors confounded in its investigation. Thus, more research is required in order to investigate the many other factors that play role in the association between farmers markets and food deserts in Texas. This research need to consider the spatial distribution of these civic activities as well as the time duration that is sufficient for it to reach its potential.

\section{Acknowledgements}

Special thanks go to Prof. Michael Orrin Way of the Texas A\&M AgriLife Research and Extension Center at Beaumont, Texas, for his help and support.

\section{References}

[1] McMichael, P. (2000) The Power of Food. Agriculture and Human Values, 17, 21-33. http://dx.doi.org/10.1023/A:1007684827140

[2] Gillespie, A.H. and Gillespie Jr., G.W. (2000) Community Food Systems: Toward a Common Language for Building Productive Partnerships. Cornell Community Nutrition Program, Division of Nutritional Sciences, Cornell University. 
http://www.cce.cornell.edu/programs/foodsystems/references.html

[3] Weber, C.L. and Matthews, H.S. (2008) Food-Miles and the Relative Climate Impacts of Food Choices in the United States. Environmental Science \& Technology, 42, 3508-3513. http://dx.doi.org/10.1021/es702969f

[4] Coleman-Jensen, A., Nord, M., Andrews, M. and Carlson, S. (2011) Household Food Security in the United States in 2010. US Department of Agriculture, Economic Research Service, ERR-125. http://www.ers.usda.gov/media/121076/err125_2_.pdf http://dx.doi.org/10.2139/ssrn.2116606

[5] Jilcott, S.B., Keyserling, T., Crawford, T., McGuirt, J.T. and Ammerman, A.S. (2011) Examining Associations among Obesity and Per Capita Farmers' Markets, Grocery Stores/Supermarkets, and Supercenters in US Counties. Journal of the American Dietetic Association, 111, 567-572. http://dx.doi.org/10.1016/j.jada.2011.01.010

[6] Lyson, T.A. (2004) Civic Agriculture: Reconnecting Farm, Food, and Community. University Press of New England, Lebanon.

[7] Brown, K.H. and Carter, A. (2003) Urban Agriculture and Community Food Security in the United States: Farming from the City Center to the Urban Fringe. http://www.foodsecurity.org/PrimerCFSCUAC.pdf

[8] Lawson, L.J. (2005) City Bountiful: A Century of Community Gardening in America. Uni, Berkeley.

[9] Leone, A.F., Rigby, S., Betterley, C., Park, S., Kurtz, H., Johnson, M.A. and Lee, J.S. (2011) Store Type and Demographic Influence on the Availability and Price of Healthful Foods, Leon County, Florida, 2008. Preventing Chronic Disease, 8, A140.

[10] Larsen, K. and Gilliland, J. (2009) A Farmers' Market in a Food Desert: Evaluating Impacts on the Price and Availability of Healthy Food. Health \& Place, 15, 1158-1162.

[11] De Lind, L.B. (2011) Are Local Food and the Local Food Movement Taking Us Where We Want to Go? Or Are We Hitching Our Wagons to the Wrong Stars? Agriculture and Human Values, 28, 273-283. http://dx.doi.org/10.1007/s10460-010-9263-0

[12] Feagan, R. and Henderson, A. (2009) Devon Acres CSA: Local Struggles in a Global Food System. Agriculture and Human Values, 26, 203-217. http://dx.doi.org/10.1007/s10460-008-9154-9

[13] Pole, A. and Gray, M. (2013) Farming Alone? What's up with the "C" in Community Supported Agriculture? Agriculture and Human Values, 30, 85-100. http://dx.doi.org/10.1007/s10460-012-9391-9

[14] Cohen, J.L. and Arato, A. (1992) Civil Society and Political Theory. MIT Press, Cambridge, MA.

[15] Domhoff, G.W. (2010) Who Rules America? Challenges to Corporate and Class Dominance. 6th Edition, McGraw Hill, New York.

[16] Poppendieck, J. (2000) Want Amid Plenty: From Hunger To Inequality. In: Magdoff, F., Foster, J.B. and Buttel, F.H., Eds., Hungry for Profit: The Agribusiness Threat to Farmers, Food, and the Environment, Monthly Review Press, New York, 189-201.

[17] Eliasoph, N. (1998) Avoiding Politics: How Americans Produce Apathy in Everyday Life. Cambridge University Press, Cambridge. http://dx.doi.org/10.1017/CBO9780511583391

[18] Somers, M.R. (2008) Genealogies of Citizenship: Markets, Statelessness and the Right to Have Rights. Cambridge University Press, Cambridge.

[19] Economic Research Service, ERS (2013) Food Access Research Atlas. http://www.ers.usda.gov/data-products/food-access-research-atlas.aspx

[20] US Census Bureau (2011) American Fact Finder. http://factfinder2.census.gov

[21] Agricultural Marketing Service, AMS (2015) Farmers Markets Directory Search. http://search.ams.usda.gov/farmersmarkets/

[22] USDA-NASS (2015) USDA National Agricultural Statistics Service Cropland Data Layer. http://nassgeodata.gmu.edu/CropScape/

[23] Anderson, W.N. (2005) Statistical Techniques for Validating Logistic Regression Models. The Annals of Thoracic Surgery, 80, 1169. http://dx.doi.org/10.1016/j.athoracsur.2005.06.049

[24] UTSPH (2009) Farmer's Market Launched to Combat Obesity. http://www.sciencedaily.com/releases/2009/01/090127211323.htm

[25] Glanz, K. and Yaroch, A.L. (2004) Strategies for Increasing Fruit and Vegetable Intake in Grocery Stores and Communities: Policy, Pricing, and Environmental Change. Preventive Medicine, 39, 75-80. http://dx.doi.org/10.1016/j.ypmed.2004.01.004

[26] Obach, B.K. and Tobin, K. (2014) Civic Agriculture and Community Engagement. Agriculture and Human Values, 31, 307-322. http://dx.doi.org/10.1007/s10460-013-9477-z 
[27] Koerber, K. (2006) Migration Patterns and Mover Characteristics from the 2005 ACS Gulf Coast Area Special Products. http://www.census.gov/newsroom/emergencies/additional/gulf_migration.html

[28] US Census Bureau (2015) Migration/Geographic Mobility. State-to-State Migration Flows. https://www.census.gov/hhes/migration/data/acs/state-to-state.html 